\title{
Self Blood (Immunotherapy) A New Hope for Psoriasis
}

\author{
Dr Avinash Shankar ${ }^{*}$, Dr Amresh Shankar², Dr Anuradha Shankar ${ }^{3}$ \\ ${ }^{I} M D$ (Internal Medicine); DNB (E\&M), Post graduate in Endocrinology \& metabolism (AIIMS-Delhi), \\ Chairman, National Institute of Health \& Research, Warisaliganj (Nawada), 805130, India
}

${ }^{2}$ BAMS (BRABU); MHA, State Health Services, Government of Bihar, Director (Hon) Aarogyam Punarjeen, Ara Garden Road Jagdeo path, Patna 14

${ }^{3}$ BAMS (BRABU), Director, Centre for Indigenous Medicine \& Research, Warisaliganj (Nawada) Bihar, 805130, India

*Corresponding Author: Dr Avinash Shankar, MD (Internal Medicine); DNB (E\&M), Post graduate in Endocrinology \& metabolism (AIIMS-Delhi), Chairman, National Institute of Health \& Research, Warisaligani (Nawada), 805130, India

\begin{abstract}
Psoriasis, a chronic non communicable, painful, disfiguring and disabling disease for which no cure and poses great negative impact on patients quality of life and can affect any age or sex. In the wake of commonly prescribed immunosuppressive or biologicals, in the present study self blood and betamethasone injection intramuscular administration as per suggested schedule achieved beginning of improvement in all the cases by $6^{\text {th }}$ month of therapy and complete absence of manifestation in all by 42 months without any adversity or withdrawal effect, considered as neutralization of generated protein responsible for increased rate of skin cell death and increased keratinocytes.
\end{abstract}

Keywords: psoriasis, communicable, disabling, immunosuppressive, self blood, cell death, keratinocytes

\section{INTRODUCTION}

Psoriasis a non-contagious, non-infectious agonising auto immune disorder usually associated with immunological disorders ${ }^{(1-10)}$, affects both sexes without any socio-economic variation and poses agonising encumbrance and progressively increasing in present scenario.
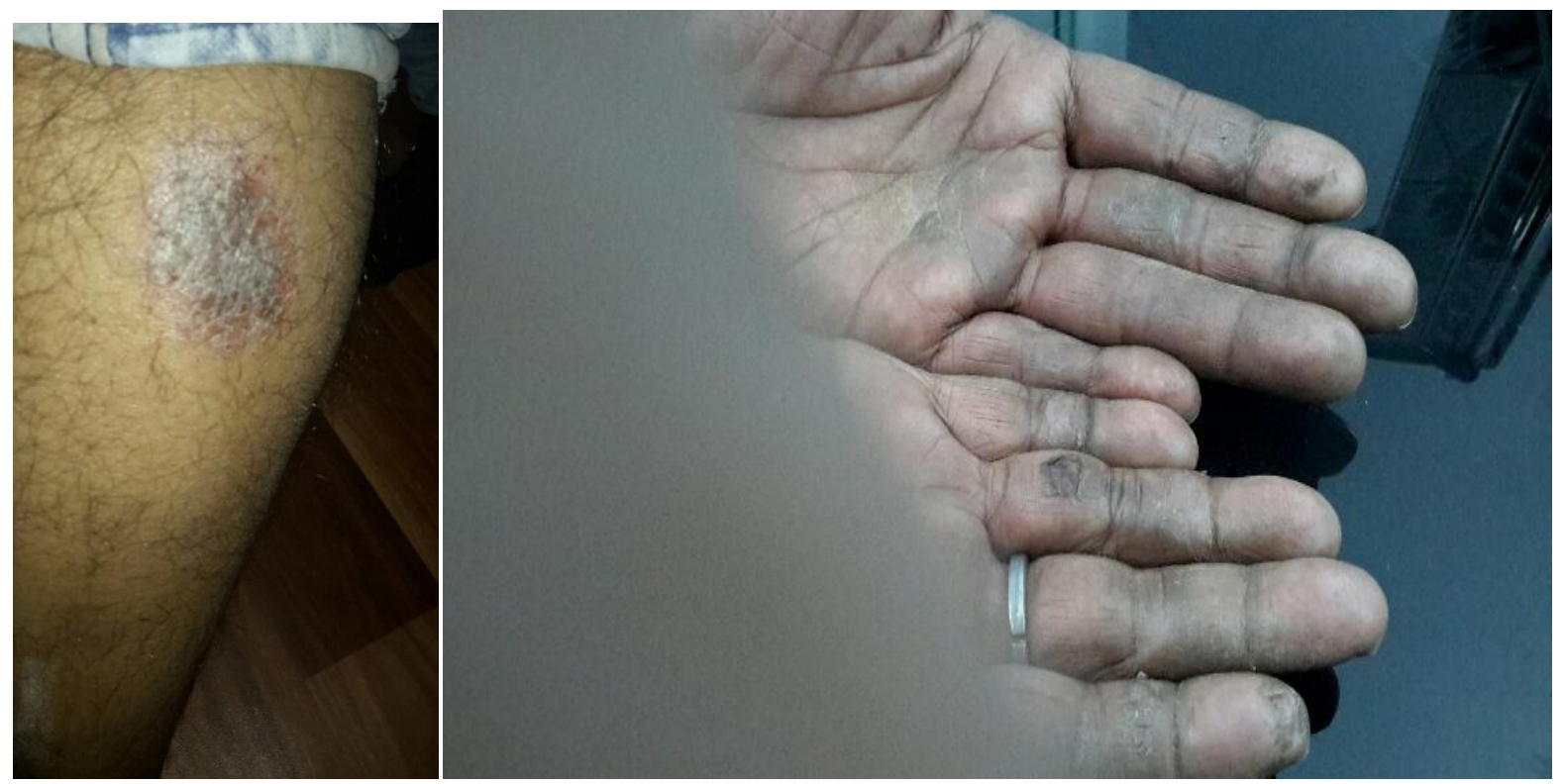

Its incidence varies worldwide i.e.- In European country USA has 1-3\% of total population, 2-4\% western world population and 7.5-8.5 million cases while in India $0.44-2.8 \%$ and affect $>10$ million every year ${ }^{(11-13)}$, rate of psoriasis incidence varies according to age, region, and ethinic \& combination of environmental and genetic factor. Commonly involved sites are knee, elbow, scalp, tarso, palm, 
sole of feet but can appear and involve any part of the body and persons with inflammatory bowel disease are more prone

Commonly offered therapeutics i.e. - modern molecule, Ayurveda, homeopath or any other, fails to ensure cure of the disease and only assure soothing effect and relieve dermal discomfort with recurrent flare up ${ }^{\text {(14-16) }}$

\section{Commonly used modern therapeutics are -}

Synthetic retinoids, Immuno suppressor, Recombiant monoclonal antibody, Cholecalciferol orally

Topical use-= Allantoin, anthralin and Desonide

\section{AIMS AND OBJECTIVES}

Evaluation of immune boosting therapeutics i.e. Self-blood and betamethasone intramuscular to counter the antigen generated in the body and calm the antigen-antibody activity in patients of psoriasis and its sequel psoriatic arthritis

\section{MATERIAL AND METHODS}

\subsection{Material}

Patients of psoriasis attending at the OPD of RA. Hospital \& Research Centre, Warisaliganj (Nawada) Bihar and Aarogyam Punarjeevan, Ram Bhawan, Ara Garden Road, Jagdeopath, Baily Road Patna 14 with following presentation were selected.

Bleeding on pulling of dry white flake of skin, a confirmatory sign of Psoriasis termed as AUSPETZ sign ${ }^{17}$

Common presentation are ${ }^{(18-19)}$

- Plaques of red skin often covered with loose silvery scales

- Itching

- Pain

- Occasionally with cracks and bleed

- Plaques of scales or crust on the scalp

- May be associated with psoriatic arthritis (stiff, swollen and painful joint )

- Thickened, ridged and pitted nail

- Stiff and swollen joint

\section{Characteristics}

Types of lesion

Pustular psoriasis: Red and scaly skin on the palms of the hands and/or feet with tiny pustules

Guttate psoriasis: Often starts in childhood or young adulthood, small, red spots, mainly on the torso and limbs. Triggers may be respiratory infections, strep throat, tonsillitis, stress, injury to the skin, and use of anti-malarial and beta-blocker medications.

Inverse psoriasis: bright red, shiny lesions that appear in skin folds, such as the armpits, groin area, and under the breasts

Erythrodermic psoriasis: Periodic, fiery redness of the skin and shedding of scales in sheets;

Duration of Study: April 2003-March 2005

Follow up Period: $\quad$ 2015-2018 


\subsection{Methods}

Selected patients were interrogated for the history of diseases, drugs taken and their response, examined clinically and investigated for typing the lesion, base line biological status to adjudge the clinical effect or adversity.

Selected patients were classified in to various grade of severity as per clinical presentation ${ }^{(19-20)}$

\section{Intensity:}

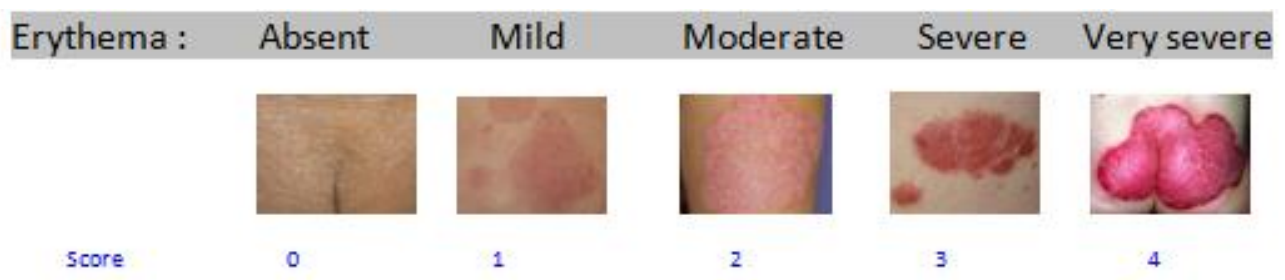

Induration (thickness)

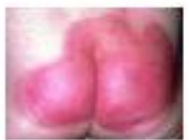

score

0

Desquamation

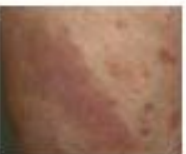

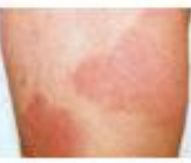

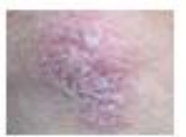

1

1
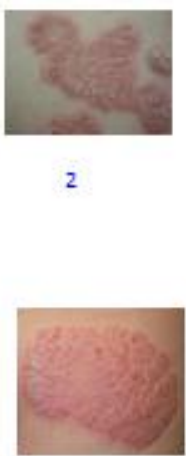
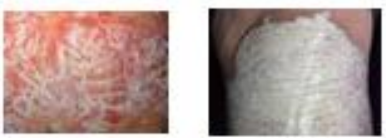

4
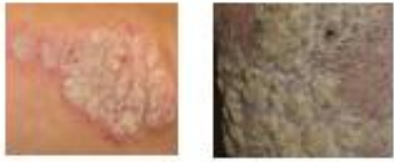

3

4

Area

The percentage area affected by psoriasis is evaluated in the four regions of the body. In each region, the area is expressed as -

\begin{tabular}{|l|l|}
\hline Area involved & Grade of severity \\
\hline Nil & $(0)$ \\
\hline $1-9 \%$ & $(1)$ \\
\hline $10-29 \%$ & $(2)$ \\
\hline $30-49 \%$ & $(3)$ \\
\hline $50-69 \%$ & $(4)$ \\
\hline $70-89 \%$ & $(5)$ \\
\hline $90-100 \%$ & $(6)$ \\
\hline
\end{tabular}

- Head and neck

- Upper limbs

- Trunk

- Lower limbs

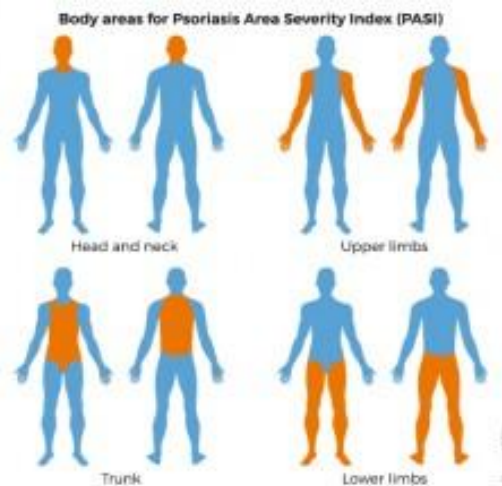




\section{Calculations for Area}

Each of the body area scores is multiplied by the area affected.

- $\mathrm{B} 1 \times(0$ to 6$)=\mathrm{C} 1$

- $\mathrm{B} 2 \times(0$ to 6$)=\mathrm{C} 2$

- $\mathrm{B} 3 \times(0$ to 6$)=\mathrm{C} 3$

- $\mathrm{B} 4 \mathrm{x}(0$ to 6$)=\mathrm{C} 4$

Thus total PASI score $=\mathrm{C} 1+\mathrm{C} 2+\mathrm{C} 3+\mathrm{C} 4$.

\section{Other Assessments}

The Cardiff Dermatology Life Quality Index is a simple 10-question validated questionnaire to assess the impact of a skin disease on the patient's life. The same team have devised a specific assessment for the quality of life in psoriasis, the Psoriasis Disability Index.

Based on these index patients were classified as-

\begin{tabular}{|l|l|}
\hline Mild: Involved body surface area (BSA) & $<10$ \\
\hline Psoriasis Area severity index (PASI) & $<10$ \\
\hline Dermatology life quality index (DLQI) & $<10$ \\
\hline $\begin{array}{l}\text { Moderate to Severe: } \\
\text { Involved body surface area (BSA) }\end{array}$ & $>10$ \\
\hline Psoriasis area severity index (PASI) & $>10$ \\
\hline Dermatology life quality index (DLQI) & $>10$ \\
\hline
\end{tabular}

In addition this can be categorised as -

\begin{tabular}{|l|l|}
\hline Grades of severity & Characteristics \\
\hline Mild: & Few scaly patch with itch \\
\hline Moderate: & $\begin{array}{l}\text { Wide spread scaly lesion and associated bleeding on } \\
\text { pulling scales. }\end{array}$ \\
\hline Severe: & $\begin{array}{l}\text { Wide spread silvery patch or scales with generalised } \\
\text { itch, swelling and agonising pain in joints. }\end{array}$ \\
\hline
\end{tabular}

After complete interrogation and clinical grading as per severity each patients were advocated the esteemed immune booster -

Self blood $2 \mathrm{ml}$ with Betamethasone $1 \mathrm{ml}$ (in non diabetic cases as per following schedule in patients as adjuvant in tapering dose schedule and other continuing drugs are withdrawn

Schedule of therapy:

Every $4^{\text {th }}$ day, week, $10^{\text {th }}$ day, $15^{\text {th }}$ day, monthly, 2 month, 3 months and 6 months for 10 injections each

On competition of therapy therapeutic outcome is assessed as per following index of assessment.

\begin{tabular}{|l|l|}
\hline Clinical grades & Characteristics \\
\hline Grade I & $\begin{array}{l}\text { Complete alleviation of clinical presentation without } \\
\text { any residue, withdrawal or adjuvant or adversity }\end{array}$ \\
\hline Grade II & $\begin{array}{l}\text { Marked relief in clinical presentation but recurrence } \\
\text { on treatment withdrawal }\end{array}$ \\
\hline Grade III & No response of therapy except transient relief. \\
\hline
\end{tabular}

\section{Observation}

Selected patients were of age group 20-60 years and majority 186 were of age group 50-60 yrs. Out of all 264 were male and 155 were female

Table1. Distribution of patients as per age and sex

\begin{tabular}{|l|l|l|l|}
\hline Age group (in yrs) & Number of patients & Total \\
\hline & Male & Female & 13 \\
\hline $20-30$ & 10 & 03 & 75 \\
\hline $30-40$ & 50 & 28 & 142 \\
\hline $40-50$ & 94 & 48 & 186 \\
\hline $50-60$ & 110 & 76 & 419 \\
\hline Total & 264 & 155 & \\
\hline
\end{tabular}




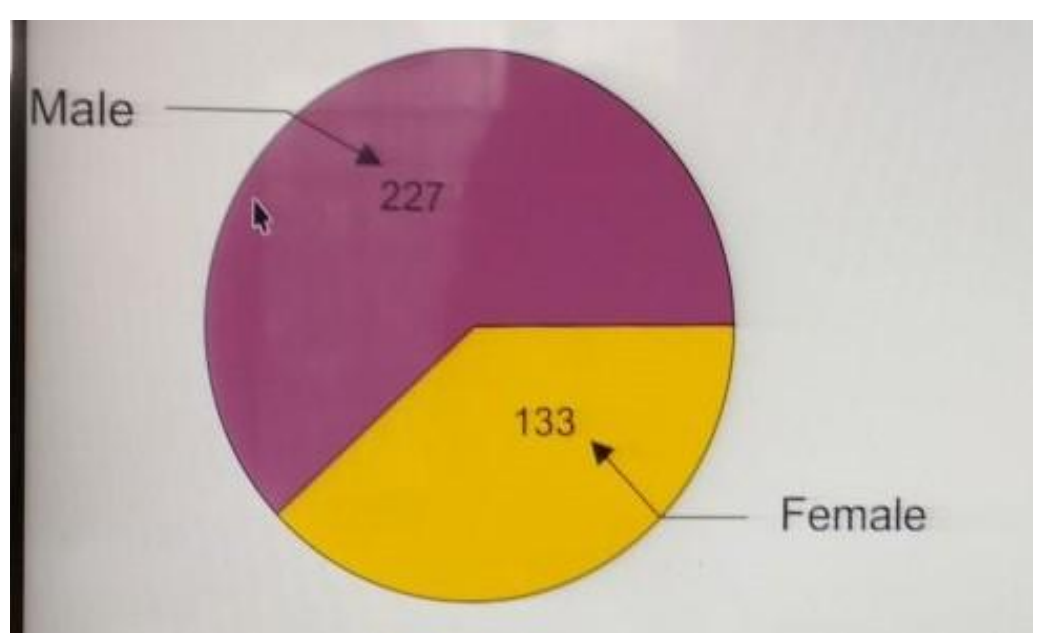

Pie diagram showing male female composition

As per distribution of lesion 164 were having lesion on extremity while 56 were having wide spread lesion and 90 presented with psoriasis sequel.

Table2. Distribution of patients as per distribution of lesion

\begin{tabular}{|l|l|}
\hline Area of distribution & Number of patients \\
\hline Localised: & 273 \\
\hline Face & 039 \\
\hline Extremity & 164 \\
\hline Abdomen & 070 \\
\hline Wide spread & 056 \\
\cline { 1 - 2 } Sequel: & 090 \\
\hline Psoriatic arthritis & \\
\hline
\end{tabular}

252 patients were suffering from 5-10 yrs. though 11 cases were suffering since more than $20 \mathrm{yrs}$.

Table3. Distribution of patients as per duration of illness

\begin{tabular}{|l|l|l|l|}
\hline Duration of illness (in yrs) & Number of patients & Total \\
\hline & Male & Female & 25 \\
\hline$<5$ & 15 & 10 & 252 \\
\hline $5-10$ & 152 & 100 & 57 \\
\hline $10-15$ & 40 & 17 & 74 \\
\hline $15-20$ & 50 & 24 & 11 \\
\hline$>20$ & 07 & 04 & 04 \\
\hline
\end{tabular}

Out of all selected cases 50 cases have not taken any treatment while 57 cases have tried all sorts of medication.

Table4. Distribution of patients as per therapeutic consumed

\begin{tabular}{|l|l|l|l|}
\hline Medication consumed & Number of patients & Total \\
\hline & Male & Female & 90 \\
\hline No treatment & 51 & 39 & 138 \\
\hline Modern medication & 70 & 68 & 120 \\
\hline Ayurvedic & 96 & 24 & 64 \\
\hline Homeopath & 40 & 24 & 57 \\
\hline All types & 32 & 26 & 27 \\
\hline
\end{tabular}

Out of all 383 cases were qualified and middle upper class people

Table5. Distribution of patients as per social and educational status

\begin{tabular}{|l|l|l|l|}
\hline Particulars & Number of patients & Total \\
\hline & Male & Female & 383 \\
\hline Qualified middle-upper class & 237 & 146 & 36 \\
\hline Illiterate \& down trodden & 27 & 09 & 09 \\
\hline
\end{tabular}


Out of all $1.5 \%$ male and $4.5 \%$ female show altered hepatic function, $39.2 \%$ male and $24.6 \%$ female present with albuminuria ,37.1\% male and $38.7 \%$ female are anaemic with Haemoglobin $<10 \mathrm{gma} \%$, $2.27 \%$ male and $4.5 \%$ female were hyperglycaemic

Table6. Shows basic bio status

\begin{tabular}{|l|l|l|l|}
\hline Basic profile & Number of patients & \multicolumn{2}{l|}{} \\
\hline & Male & Female & Total \\
\hline $\begin{array}{l}\text { Hepatic profile: } \\
\text { SGOT: }\end{array}$ & & & \\
$<35$ & 260 & 148 & 408 \\
$>35$ & 04 & 07 & 11 \\
\hline $\begin{array}{l}\text { SGPT } \\
<35\end{array}$ & 260 & 148 & \\
$>35$ & 04 & 07 & 408 \\
\hline $\begin{array}{l}\text { Renal profile: } \\
\text { Blood urea: }\end{array}$ & & & 11 \\
$<26$ & 264 & 155 & \\
$>26$ & None & None & 419 \\
\hline $\begin{array}{l}\text { Serum creatinine } \\
<1.5\end{array}$ & 264 & 155 & None \\
$>1.5$ & None & None & 419 \\
\hline $\begin{array}{l}\text { Urine Albumin } \\
\text { Present }\end{array}$ & 104 & 65 & None \\
Absent & 160 & 90 & 169 \\
\hline $\begin{array}{l}\text { Hematology: } \\
\text { Hemoglobin(gm \%) }\end{array}$ & & & 250 \\
$<10$ gm\% & 98 & 60 & \\
$>10$ gm\% & 166 & 95 & 158 \\
\hline $\begin{array}{l}\text { Absolute eosinophil : } \\
<400 / c c\end{array}$ & 264 & 155 & 261 \\
$>400 /$ cc & none & none & 419 \\
\hline $\begin{array}{l}\text { Blood Sugar } \\
\text { Fasting }\end{array}$ & 258 & & None \\
$<100$ mg\% & 06 & 07 & \\
$>100 \mathrm{mg} \%$ & & & 406 \\
\hline
\end{tabular}

Out of all 10\% (42) were of mild grade while 34.9\% (146) were of grade III severity (Bar diagram)

Table7. Showing outcome of therapy

\begin{tabular}{|l|l|}
\hline Characteristics & Number of patients \\
\hline Gade of therapeutic response: & 396 \\
I & 23 \\
II & Non \\
\hline III & Non \\
\hline Bio status: & Non \\
Altered & Non \\
Drug related adversity & \\
\hline
\end{tabular}

Majority $46.3 \%$ (194) cases have taken 4 months to begin improvement in agonizing presentation where as 48 cases shown improvement on 3 months completion of therapeutic regime and 68 case taken 6 months' time (Bar diagram)

Bar diagram showing time lapse for onset of improvement 


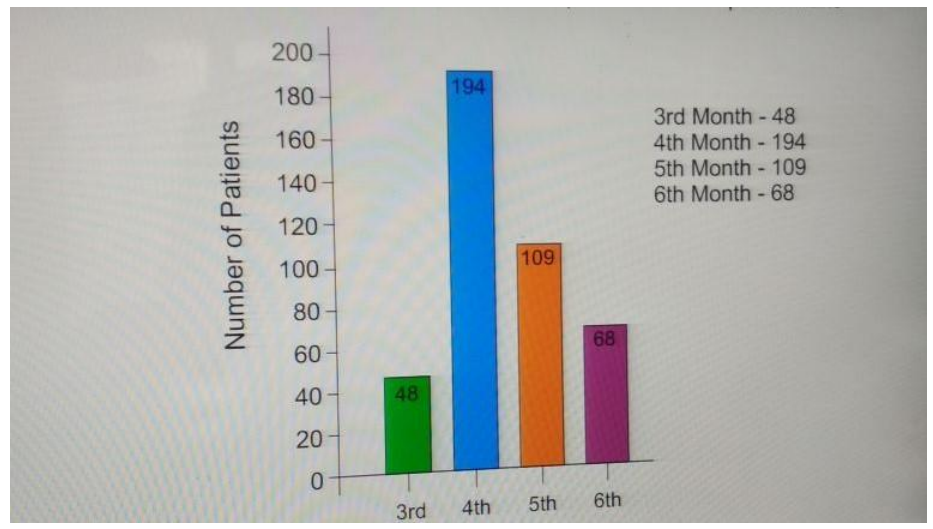

Pie diagram showing distribution of patients as per degree of severity

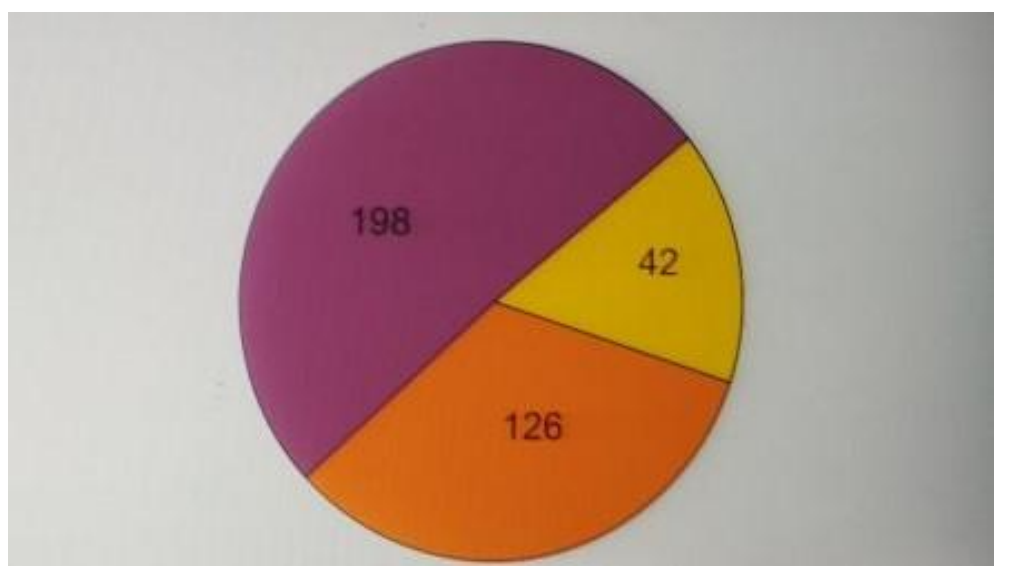

mild, moderate, severe

Complete cessation of agonizing presentation achieved after 6 months therapy and by 3 yrs majority patients $94.5 \%$ (396) had complete relief of presenting features and agonising itch (Graph showing achievement of recovery)

Graph showing therapeutic response

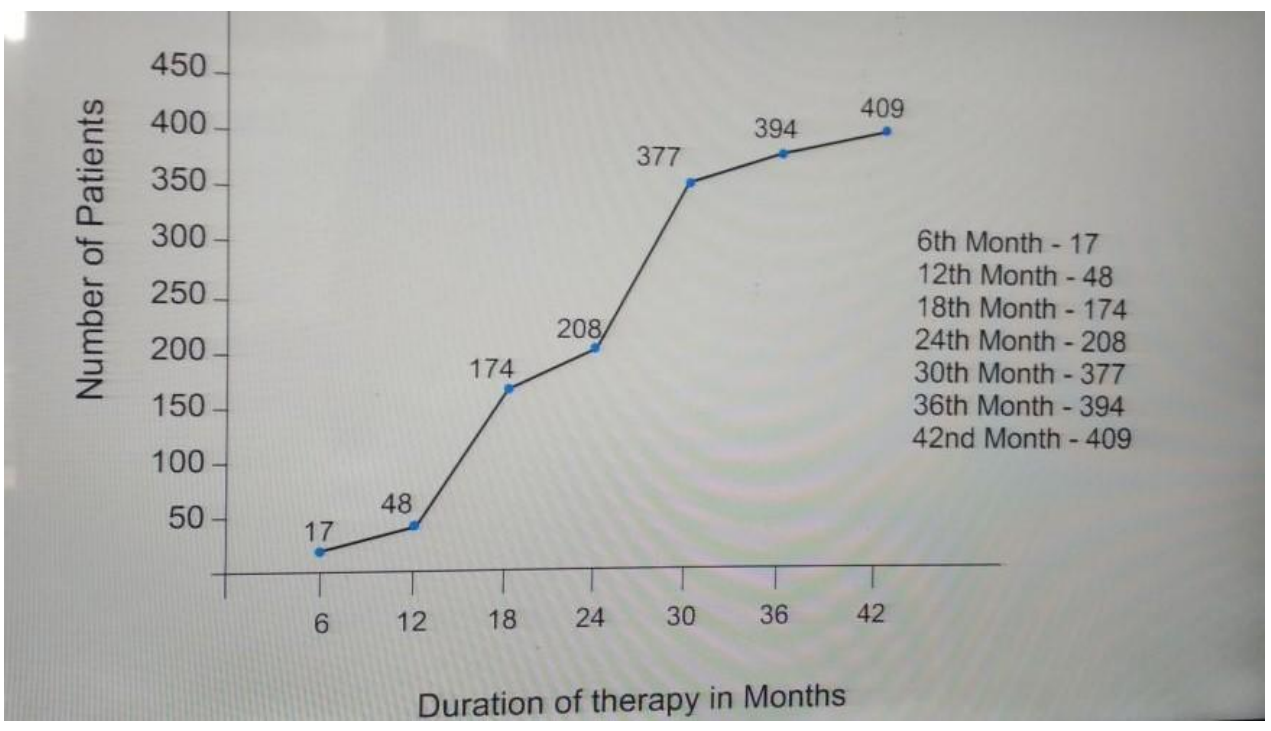

Out of all 94.\% (396) patient had grade I clinical response while rest grade II without any relapse or withdrawal reflex or any adversity related to therapeutic regime nor any disease related sequel during the vigil follow up.

\section{RESULT}

94\% patients of psoriasis of varied degree of severity had complete cessation of agonizing presentation in 3 years without any supplementation, drug adversity, therapy withdrawal sequel. 


\section{DISCUSSION}

Psoriasis, a result of abnormal excessive and rapid growth of epidermis layer of skin and premature maturation of keratinocyte inducing dermal inflammatory cascade involving dendritic cell, macrophages and $\mathrm{T}$ cells which move from the dermis to epidermis and secrete inflammatory chemical signals (Cytokine) i.e.- interleukin 36¥, tumour necrosis factor- $\alpha$, interleukin and interleukin 6 and 22. ${ }^{(21-24)}$

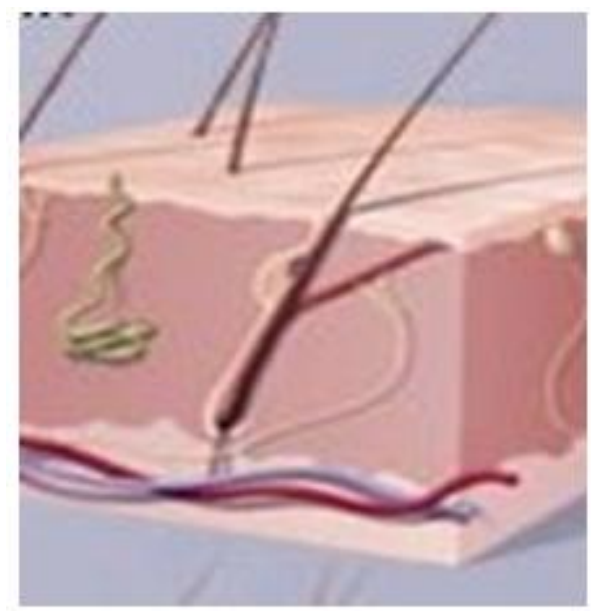

(Normal skin)

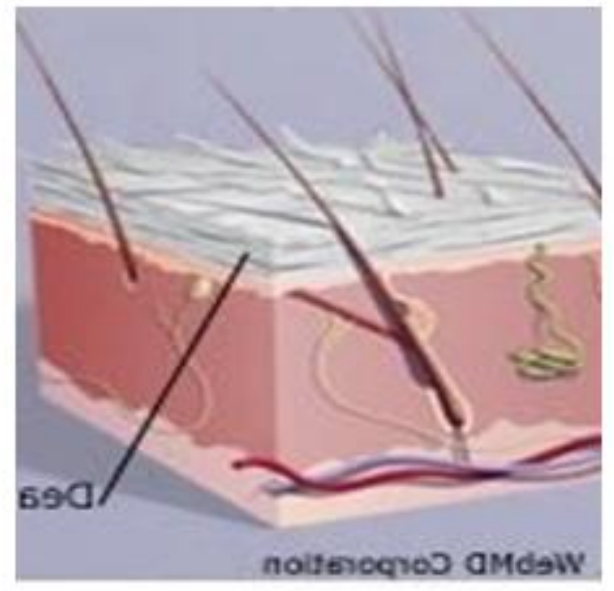

(Psoriatic skin)

DNA released from dying cells acts as an inflammatory stimulus and stimulate dendritic cell.

The present study showing complete relief of presentation and non-had any recurrence, relapse or any drug or disease related untoward effects suggest immunological improvement by self-blood due to generation of specific antibody which binds with specific protein and check cell death rate, curb $\mathrm{T}$ cell, block Tumour necrosis factor (TNF- $\alpha$ ) and stop release of chemical messenger and limit dendrite cell and favours Th2 cells Cytokine secretion pattern over a Th1/Th17cell cytokine profile Dendritic cell bridge the innate immune system and adaptive immune system. ${ }^{(25-32)}$

Betamethasone calm the antigen and antibody reaction and alleviate the presentation.

\section{REFERENCES}

[1] Kaur I, Kumar B, Sharma VK, Kaur S. Epidemiology of psoriasis in a clinic from north India. Indian J Dermatol Venereol Leprol 1986;52:208-12

[2] Bedi TR. Psoriasis in north India. Geographical variations. Dermatologica 1977; 155:310-4.

[3] Christophers E. Psoriasis - epidemiology and clinical spectrum. Clin Exp Dermatol 2001; 26:314-320.

[4] Lomholt G. Prevalence of skin diseases in a population: a census study from the Faroe Islands. Dan Med Bull 1964; 11:1-7.

[5] Hellgren L. Psoriasis: The prevalence in sex, age and occupational groups in total populations in Sweden. Morphology, inheritance and association with other skin and rheumatic diseases. Stockholm: Almquist and Wiksell; 1967

[6] Brandrup F, Green A. The prevalence of psoriasis in Denmark. Acta Derm Venereol 1981; 61:344-6.

[7] Farber EM, Nall L. The Natural history of psoriasis in 5,600 patients. Dermatologica 1974; 148:1-18.

[8] Okhandiar RP, Banerjee BN. Psoriasis in the tropics: An epidemiological survey. J Indian Med Assoc 1963; 41:550-6.

[9] Bedi TR. Clinical profile of psoriasis in North India. Indian J Dermatol Venereol Leprol 1995; 61:202-5.

[10] Kaur I, Handa S, Kumar B. Natural history of psoriasis: a study from the Indian subcontinent. J Dermatol $1997 ; 24: 230-4$.

[11] Amanda Oakley, PASI Score,Derm Net NZ /2009

[12] Global report on Psoriasis,WHO psoriasis 2016

[13] Moll JM, Wright V. Psoriatic arthritis. Semin Arthritis Rheum 1973; 3:5578.

[14] Gladman DD, Rahman P. Psoriatic arthritis. In: Ruddy S, Harris ED, Sledge CB, editors. Kelly's textbook of Rheumatology. $6^{\text {th }}$ ed. Vol 2. Philadelphia W.B Saunders Company; 2001. p. 1071-9. 
[15] Rajendran CP, Ledge SG, Rani KP, Madhavan R. Psoriatic arthritis. J Assoc Physicians India 2003; 51:1065-8.

[16] Prasad PV, Bikku B, Kaviarasan PK, Senthilnathan A. A clinical study of psoriatic arthropathy. Indian J Dermatol Venereol Leprol 2007; 73:166-70.

[17] Ray SPC, Singh T, Kaur I, Suri S, Sehgal S, Kaur S. Clinical profile of psoriatic arthropathy. Indian J Dermatol Venereol Leprol 1990;56:200-3

[18] Shah NM, Mangat G, Balakrishnan C, Joshi VR. Psoriatic arthritis - a study of 102 patients. J Indian Rheumat Assoc 1995;3:133-6

[19] Nadkar MY, Kalgikar A, Samant RS, Borges NE. Clinical profile of psoriatic arthritis. J Indian Rheumat Assoc 2000;8:S40

[20] Kononen M, Torppa J, Lassus A. An epidemiological survey of psoriasis in the Greater Helsiniki area. Acta Derm Venereol Suppl (Stockh) 1986;124:1-10

[21] Kammer GM, Soter NA, Gibson DJ, Schur PH. Psoriatic arthritis: a clinical, immunologic and HLA study of 100 patients. Semin Arthritis Rheum 1979;9:75-97.

[22] Robert ME, Wright V, Hill AGS, Mehra AC. Psoriatic arthritis - follow up study. Ann Rheum Dis 1976;35:206-19

[23] Gisondi P, Tessari G, Conti A, Piaserico S, Schianchi S, Peserico A, et al. Prevalence of metabolic syndrome in patients with psoriasis: a hospital-based case-control study. Br J Dermatol 2007; 157:68-73.

[24] Takahashi H, Takahashi I, Honma M, Ishida-Yamamoto A, Iizuka H. Prevalence of metabolic syndrome in Japanese psoriasis patients. J Dermatol Sci 2010;57:143-4.

[25] Wilczek A, Sticherling M. Concomitant psoriasis and bullous pemphigoid: coincidence or pathogenic relationship? Int J Dermatol 2006; 45:1353-7.

[26] Yasuda H, Tomita Y, Shibaki A, Hashimoto T. Two cases of subepidermal blistering disease with antip200 or 180-kD bullous pemphigoid antigen associated with psoriasis. Dermatology 2004; 209:149-55.

[27] Sandhu K, Kaur I, Kumar B. Psoriasis and vitiligo. J Am Acad Dermatol 2004;51:149-50.

[28] de Arruda LH, De Moraes AP. The impact of psoriasis on quality of life. Br J Dermatol 2001; 144:33-6.

[29] Ashcroft DM, Li Wan Po A, Williams HC, Griffiths CE. Quality of life measures in psoriasis: a critical appraisal of their quality. J Clin Pharm Ther 1998; 23:391-8. ]

[30] Rakhesh SV, D'Souza M, Sahai A. Quality of life in psoriasis: a study from south India. Indian J Dermatol Venereol Leprol 2008; 74:600-6. ]

[31] Gaikwad R, Deshpande S, Raje S, Dhamdhere DV, Ghate MR. Evaluation of functional impairment in psoriasis. Indian J Dermatol Venereol Leprol 2006; 72:37-40.

[32] Matto SK, Handa S, Kaur I, Gupta N, Malhotra R. Psychiatric morbidity in vitiligo and psoriasis: A comparative study from India. J Dermatol 2001;28:424-3

Citation: A. Shankar et al., "Self Blood (Immunotherapy) A New Hope for Psoriasis", International Journal of Clinical Chemistry and Laboratory Medicine (IJCCLM), vol. 4, no. 1, pp. 16-24, 2018. http://dx.doi.org/10. 20431/2455-7153.0401005

Copyright: (C) 2018 Authors. This is an open-access article distributed under the terms of the Creative Commons Attribution License, which permits unrestricted use, distribution, and reproduction in any medium, provided the original author and source are credited. 